\title{
The Bourdieuan Triangle of Journalism, Political and Economic Fields: Brief Milestones of Indonesian Journalism in Surabaya
}

\author{
NANANG KRISDINANTO \\ Widya Mandala Catholic University, Surabaya \\ ACHMAD SUPARDI \\ President University, Cikarang, Indonesia
}

\begin{abstract}
The focus of this study is journalism in Surabaya, Indonesia's second largest city, home to numerous print media and was a hotspot for Indonesia's independence struggle against the colonial ruler. It utilises Bourdieu's conceptions on field, capital, and habitus as the main framework to elaborate tensions, resistance, and dynamics in journalism during the final years of the colonial period and the ear of Old Order, New Order and Reform. Analysis on archives and interviews with key sources found that the journalistic field in Surabaya, and Indonesia in general, was linked closer to politics during the Colonial and Old Order eras, characterized by resistance against colonial ruler and partisanship in supporting the newly founded political parties. However, this character shifted drastically during the New Order and Reform eras during which Indonesia's journalism was more closely connected to economics that created the emergence of commercial press. Surabaya Post, the Surabaya-based local newspaper that dominated the newspaper market in East Java Province during 1970s-1990s positioned itself as an evening newspaper while all other newspapers were morning newspaper. It also positioned itself as independent while almost all other big newspapers at the time were partisan and became the megaphone for political parties. This positioning was carefully chosen by Surabaya Post in order to gain more financial reward. It marked the emergence of commercial press and the shift of dominant external power influencing the dynamics of journalism from politics to economics.
\end{abstract}

Keywords: Journalistic field, Surabaya, commercial press, press of struggle, colonial.

\section{INTRODUCTION}

Commercialization of media which leads to media conglomeration, shrinks the diversity of opinion which audience can get. In Indonesia, there are 13 media conglomerates that control hundreds of TV and radio stations, print media and on-line news outlets (Lim, 2012). Therefore, although Indonesians are exposed to various media products, they are actually exposed to only 13 slightly different opinion and political stances. It is what Bourdieu denounced as "homogenization of newspapers and their 'de-politicization"” (Bourdieu, 2001, p.23). Realizing the important implication of media conglomeration to opinion pluralism within a society, this paper investigates how media commercialization, the seed for media conglomeration, took place in Indonesia.

This paper provides an overview of when, how and why the commercialization permeated into and suppressed journalism in Surabaya as an important part Indonesia's media landscape. It elaborates economic and political dynamics which took place within and influenced the course of journalism in Surabaya since its birth in the Dutch Colonial era up to the Reform era. This paper also investigates Bourdieu's assertion that social fields, including journalism, "impose their own internal rules of organization" by which any actors 
entering the field are "obliged to play by its own autonomous rules of the game" which are incidentally not autonomous due to political and economic pressures (Compton \& Benedetti, 2010, p.489).

\section{LITERATURE REVIEW}

Bourdieu described field as a "separate social universe" which has its own logic as well as "field of power", "site of struggles" and "spaces of possibilities" for agents to determine their positions within the field (Bourdieu, 1993, p.27, 30, 65, 183, 184, 203, 206, 266). It means that power relations will continuously exist among agents, be it individuals, communities, or institutions within a field or in relation to other fields.

The field here is described as a social space in which certain practices take place within their own logic. Hence, journalistic field is defined as a social space where the practices of journalism within the logic of journalism takes place. As a struggling site, Bourdieu sees the journalistic field as under the domination of other fields, especially the economic field in which they seek-for-profit logic operates. Bourdieu shared two important arguments in describing the journalistic field. First, journalistic field is always in a state of interconnected to other fields, especially the economic and political field. On his account about the television phenomenon in France, Bourdieu argued that the journalistic field has lost its autonomy to economic field because of commercialization. Bourdieu claimed that the position of journalistic field is very fragile against the pressure of external forces (Bourdieu, 1998, p.53). Secondly, the structure of the journalistic field consists of heteronomous and autonomous poles. Heteronomous pole represents an end which external actors want journalists and media institutions to head to and serve their interest. On the other hand, autonomous pole reflects an end which journalism logic operates in its purity. Autonomous pole represents specific assets of journalists and media institutions such as journalistic expertise, artistic taste and the ability to see the big picture of complex phenomena. These abilities are termed as cultural capital. Other types of capital include social capital (high-level contacts in specialized areas that enable journalist to access information and data deeper and sooner that others) and symbolic capital in the forms of public recognition of the journalist role in the society (English, 2016, p. 1002-1.003). The combination of these three capitals is what is termed as the journalistic capital.

Bourdieu also used autonomous pole and heteronomous pole terms to justify his argument that journalism, like other fields, is actually a field of power where there is always a struggle among forces within a field and between fields. Here, journalistic field is presumed as a field of struggle in which individual journalists or media organizations compete to enhance the forms of capital they have. The so-called resistance in this context is a situation when the agents (both individual and organization) within a field struggled to stay in their autonomous pole despite huge forces to drive them into the heteronomous pole (Bourdieu in Benson \& Neveu, 2010, p.4). How journalists swing between the two poles is determined, among other things, by their habitus. Bourdieu elaborates habitus as "the complex accumulation of experiences accrued through individual's practical and historical engagement with social structures, such as the economy, class, race, family, gender, etc. Out of these experiences, people internalize the possibilities and constraints of social life" (Bourdieu, 1990, p. 53-54; Bourdieu, 2005). 
Perspectives on field, capital, and habitus are used to describe the historical dynamics of Surabaya press, particularly to answer the question of the relation of Surabaya's journalistic field with political and economic fields from the Colonial era until the Reform era.

\section{METHODOLOGY}

Data for this research were taken through archival studies and interviews with journalists involved in or have sufficient knowledge about the development of journalism in Surabaya. The informants were chosen purposively. There were 22 journalists ranging from reporter to chief editors from 12 newspapers and 2 journalist associations interviewed for this study (see Appendix 1. List of Informants). Criteria for their selection are: the informants have direct experience about the topic under study; the informants have the ability to tell the story about their experience; and that they are willing to participate in the study. The identity of some of the informants was concealed due to their requests.

This article divides the development of the Indonesian press into only four periods, namely the Colonial era (final years of Dutch colonialization and the period of Japanese occupation or up to 1945); the early years of independence until the end of the Old Order (1945-1965); the New Order (1966-1998); and the Reform era (1998 onwards). In this article, the struggle within the journalistic field in Surabaya and Indonesia are elaborated simultaneously considering the fact that the struggle occurred at the local level (Surabaya) have never been separated from the struggle at the national level and vice versa.

\section{RESULTS AND DISCUSSION}

Colonial Era: The spirit of independence connects the journalistic field with the political arena

On 27 January 1933, Indonesian and Dutch sailors went on strike, rejecting a 17\% decline in the Dutch East Indies (DEI) government employee salaries decided by Dutch Governor General de Jonge. The decision was taken to ease Dutch national budget deficit caused by the world economy depression. Indonesian and Dutch sailors on board Royal Dutch Navy Ship De Zeven Provincien angrily took over the ship and brought it to Surabaya to protest. The Dutch government was completely aware that mutiny like this will inspire and boost the morale of Indonesian nationalists who fought for independence and therefore, bombed the ship as it was about to enter the Sunda Straits. Twenty local crews and 3 Dutch crews were killed while the surviving local crews were sentenced to 18 years in prison. Raden Aria Taher Tjindarboemi, chief editor of the Soeara Oemoem newspaper criticized it by writing:

For decent countries, this is nothing other than creating anarchy, carelessness, wildness, rumble, and absence of power. You guys readers think, 3,000 low-class employees went on strike [and the government responded by bombing them]. The DEI naval will be chaotic... (Ariyansyah, Ganie \& Ruslinur, 1996, bracket is mine).

Tjindarboemi also sharply criticized the colonial government news agency, Aneta, which blamed local sailors for the uprising. Not once did Tjindarboemi criticized the DEI government. Through his editorial, he vigorously denounced the ruthlessness of the colonial government, although consequently, his newspapers got warned repeatedly. He also had to 
deal with Politieke Inlichtingen Dienst (PID, Dutch Indies Political Intelligence Unit) for several times, but he always managed to escape the prison term. However, his luck worn out when he wrote a piece about the mutiny in De Zeven Provincien ship. He was arrested and lost his trial in the Court of Appeal. He was sent to Kalisosok Prison, Surabaya, then moved to Sukamiskin Prison, Bandung and finally sent to exile in Ende, East Nusa Tenggara for 20 months in prison (Ariyansyah, Ganie \& Ruslinur, 1996). The colonial government also banned Soeara Oemoem which at that time had a circulation of 2,000 copies (SPS Team, 1994, p. 34-35; Swantoro-Atmakusumah, 2002, p. 198-199).

Two things emerged from the case of Tjindarboemi and Soeara Oemoem. First, it relates to Bourdieu's argument that the field of journalism will always be connected to and influenced by other fields. While the economic field was prominent in Bourdieu's researches, the political field was the most prominent one in Surabaya. To fight the Dutchlanguage newspapers which supported Dutch colonial rulers, local journalists established newspapers in Indonesian and ethnic languages to spread nationalism and gain independence. Secondly, the struggle in the journalistic field shows what Bourdieu called as resistance, a situation when agents (newspaper organizations and journalists) continue to push the pendulum into a journalism autonomous pole and rejected external forces (Dutch colonial government) who wanted to push the pendulum into a heteronomous pole, characterized by submission to the colonial government's political agenda. The most intimidating control of the Dutch colonial government was the laws regulating newspapers, such as Haatzaai Artikelen and Persbreidel Ordonnantie that can be imposed on anyone considered as "disturbing public order" and spreading "resistance" to the government. Between 1931 and 1937, at least 37 newspapers became victims of this regulation, including the imprisonment of several journalists (Hill, 2007, p.26).

The resistance of Surabaya journalists and media institutions in their effort to maintain the autonomy from external forces was reflected also during the Japanese occupation (1942-1945) and the early years of Indonesian independence (1945-1957). At the time of the Japanese occupation, almost all national media companies were banned and their staffs were forced to join the Japanese Military Propaganda Front. The number of newspapers was limited while the journalists must sign up for re-selection. The Japanese Army Government changes the name of Soeara Oemoem (voice of the public) into Soeara Asia (the Asian voice) which reflects the presence of Japanese power in Indonesia. It was the only newspaper allowed to stay published in Surabaya. But even under intense scrutiny, Soeara Asia dared to publish a news item about the establishment of Gerakan Poetra, a nationalist movement in June 1943 which was against the interest of Japanese military authority. The newspaper also dared to publish the motto of Surabaya freedom fighters: "we are willing to die tonight as long as we got our independence the morning before." The bravery of Soeara Asia culminated in the proclamation of the Republic of Indonesia's independence on 17 August 1945 through a stop press and leaflets circulated throughout the city. The Japanese military government was furious and forced the editors to revoke the news. The pressure was fiercely yet smartly opposed by publishing the text of the independence proclamation on the newspaper's 20 August 1945 edition with larger red letters (SPS Team, 1994, p. 54-55).

The early days of independence (1945-1957) were also marred by conflicts related to Dutch Military Aggression (I and II) which marked the heroism among local journalists. A group of young journalists, Abdoel Azis, Toety Azis and Hasan Altuwy, who were Berita 
newspaper journalists, published their newspaper in red ink and displayed Indonesia's Red and White flag on the front page with the caption: "Here is the banned flag" on 16 August 1949. The Red and White flag was forbidden to be hoisted in the Dutch occupied territory at that time. East Java, especially Surabaya in the period of 1945-1950 was therefore an ideal description of the press of struggle (Siahaan \& Purnomo 1993, p.44).

At this point, it can be seen that the external pressure towards the press did not come from profit-seeking needs, but from the political field. The dramatic struggle among journalist at that time was made possible by their habitus, the mental structures that actors use to face and live a social life. The actors were equipped with series of internalized schemes to feel, understand, and judge the social world through which they produce their actions (Ritzer \& Goodman, 2004, p.522). In the context of journalistic field, the social condition at that time puts journalists in a unique position: journalist and patriot. Fighting colonial ruler became a value absorbed by journalists and internalized within themselves which then transformed into habitus.

The journalistic field in Surabaya at that time defied Bourdieu assertion that the autonomous pole is better defended by actors who have sufficient cultural capital. Journalists and press companies in Surabaya at that time were able to maintain an autonomous position although they have inadequate cultural capital. Journalism competence among journalist was very low, yet their degree of autonomy was very high. Setiono (2008, p.239) noted:

In those days, the quality of the press was still very low, whose content was mostly marred by abusive and filthy curses along with a number of vilifying slander and were also very subjective.

\section{Old Order Era: 'Survival' in the Midst of Political Turbulence}

The field of journalism was still under the pressure of the political field during this era, only the origin of the pressure was different. In the colonial era, colonial power was the origin of pressure while in Old Order era it was the newly born Indonesian Government and the political parties that fought to garner mass support. Political turbulence in the political field continually suppressed the structure of the journalistic field to move closer to the heteronomous pole as reflected in the emergence of the partisan press (1945-1957) and the guided press (1957-1965). Referring to Hanazaki (1998, p.6), the partisan press emerged as a result of overemphasizing the spirit of freedom, a euphoric response towards independence.

The cacophony of partisan press led Sukarno to implement the so-called guided democracy. Soekarno imposed all Indonesians to be loyal to the ideology of Nasakom (nationalism, religion, and communism) and did not hesitate to ban newspapers that were against it. At that time, almost all newspapers were affiliated with political parties and mass organizations, be it explicitly or implicitly. Consequently, editorial and management staffs were nominated by the political party. The bright side of this scheme was that newspapers with strong affiliations to political parties tend to have no problem with circulation.

The most spectacular example, as noted by Hill (2007, p. 29-30), was Harian Rakyat which was affiliated with the Indonesian Communist Party (PKI). From a circulation of just 2,000 copies in 1951, this newspaper soared into 58,000 in 1956 and became the largest newspaper at that time. The other newspaper was Pedoman which was affiliated with a 
small but influential Indonesian Socialist Party and gained a circulation record of 48,000 copies. The Indonesian National Party (PNI) was affiliated with Suluh Indonesia, a daily with around 40,000 circulations while the Masyumi Party was affiliated with Abadi, a daily with 34,000 circulation copies. These four newspapers' performance was extraordinary given the fact that most other newspapers can barely sell 10,000 copies or less (Atmakusumah in Surjomihardjo, 1980, p.188). Most newspapers faced financial problems and can only survive because of the chief editor's lobbyist who pour their money whenever the chief editor calls them for help.

Indonesia Raya and its chief editor, Mochtar Lubis was a good example. Whenever Indonesia Raya lacks money to pay journalists' salary, to buy papers, or to finance other things, Mochtar Lubis simply picked up the phone to get the money he needed. According to Hill (2011, p.271), Mochtar Lubis admitted the financial gap between income and expenditure was taken care of, by "his friends".

This condition reflects the imbalance intersection among the three fields (journalism, political and economic) in which political field and economic field were consistently pushing the journalistic field away from its autonomous pole.

Another evidence of the intersection between the three fields was seen from the Indonesian media's dependence on import paper which was increasingly difficult to obtain due to the continued weakening of the exchange rate. The government subsidized the paper so that newspaper publishers can improve their circulation. But what really happened was that publishers often sold $30 \%$ to $50 \%$ of their newspaper quotas at the black market in order to increase their income. The quotas were set by the Newspaper Publishers Union (SPS) according to members' reported circulation figure, which were of course much greater than the actual number, sometimes even more than threefold. This practice was made possible by the fact that the price of printing paper in black market can reach tenfold of the price set by SPS. Siahaan and Purnomo $(1993$, p.69) said that many publishers of that time acted more like paper merchants than newspaper publishers. Hanazaki $(1998$, p.18) noted that in 1961 alone there were 61 newspapers with a circulation of 692,500 copies. Four years later, that number rose to 114 newspapers with a total circulation of 1,469,350 copies. This is a disastrous situation concerning Indonesia's dependence on the imported paper which was increasingly difficult to obtain due to the weakening of rupiah exchange rate.

While the journalistic field seemed to be absorbed into the political field, there was also a connection with the economic field as seen through the financing structure of Indonesia Raya and the establishment of Surabaya Post. Hill (2007) and Sen and Hill (2007) argued that the collapse of Old Order in 1966 marked the turning point of the press from previously acting as an ideological tool serving the interests of political groups to now, serving new market interests. Surabaya started this shift earlier through the establishment of Surabaya Post in 1953.

Surabaya Post was established more in response to the newspaper market and advertising that began to flourish at that time rather than responding to political revolution. This can be seen from several aspects. First, Surabaya Post built its positioning as an afternoon newspaper while most others were morning newspapers. Second, the motto which said, "Merdeka, non partai" (independent, non-party) was a stark opposition to the norm at that time when most newspapers were affiliated with political parties. A year before the 1955 election (the first election in Indonesian history), there were 27 newspapers in Jakarta. The four largest were Harian Rakyat and Sin Po (both affiliated to Indonesia 
Communist Party/PKI), Pedoman (Indonesian Socialist Party oriented/PSI), Suluh Indonesia (organ of the Nationalist Party of Indonesia/PNI), and Abadi (organ of the Masjumi Party). In addition, many dailies in Jakarta were also closely related to political parties. Merdeka, for example, was associated to PNI, Duta Masyarakat was the organ of Nahdlatul Ulama (Hanazaki, 1998, p. 13-14). Third, this unusual motto was then related to readership segmentation aimed by Surabaya Post. With such a motto, Surabaya Post can be marketed to a niche market who relatively well-educated in the Colonial and early independence period such as indigenous intellectual communities (ambtenaaren in Dutch), urban nationalists, ethnic Chinese traders, and the new middle class although their number at that time was not large. Demographically, Surabaya Post was targeting the readers who live in the colonial-era staads gementee or downtown, not in a kampong (cramped residential area which usually house the middle-low citizens) (LP3Y Team, 2006, p.432).

The fourth aspect is the advertisement. At this point, advertising becomes a source of income other than the newspaper subscription fee. Good business calculation and mature marketing strategy helped Surabaya Post to attract a number of advertisements right from its first publication on April 1, 1953. This non-party positioning resulted in greater trust among the industries and business people which later attract more advertisements (Tim Reporter Surabaya Post in Siahaan \& Purnomo, 1993, p. 67-68).

The logic of profit-seeking derived from the field of the economy began to infiltrate the journalistic field which Sen and Hill (2007) referred to as "the commercial press". In Bourdieuan perspective, it was the time when the Indonesian journalistic field begun to be intensely connected to the economic field.

\section{New Order Era: Commercialization under Double Control}

The journalism field remained under pressure during the New Order era. However, the ideology of the New Order which prefers economic growth opened up space for the transformation of capital in many sectors, including media, creating the overlap between journalistic field and economic field in an intense scale. Publishing newspaper was seen as a profitable business and investment, while news item is positioned not only as information that inflames a certain political spirit but also as a commodity that can be sold. Publishers shift their paradigm from seeing the financial benefit as a mere bonus of something noble they did (fighting the colonial ruler or assisting political struggle) to seeing it as a mustachieved target.

Referring to McManus (in Jorgensen \& Hanitzsch (Ed.), 2009, p.218), commercialization can be defined as transforming something into a business. The issue of commercialization arose in accordance with the rise of profit-making in the form of selling news-like advertisement or displaying a series of report serving the interest of external partner. It is admitted by some informants:

I think this [displaying news-like ads] is legit. Many other media companies do the same. Media companies will not survive and grow without this [revenue from advertisement] (NDH, journalist and advertorial manager of Radar Surabaya, personal interview on 13 April 2016, square bracket is mine). 
The ideal situation now is that journalists must have two legs [one in newsroom and one in business unit looking for revenue]. ... People said that it will poison the way journalists do their job, but I think it [the impacted journalism works due to journalists' revenue-seeking activities] is only about 15\% (EPT, journalist of Surabaya Post 1988-2010, personal interview on 6 February 2016, square bracket is mine).

The success story of Surabaya Post which grew as a steady evening newspaper and the rise of media conglomerates such as Kompas and its group can be seen as a confirmation of the overlap between journalistic field and the economic field that implied the birth of commercialization. Hence the logic which operates in the journalistic field incorporates also the logic of the economic arena. That is why Bourdieu argued that journalistic field is a semi-autonomous field since it cannot live only its own law or operate on its own logic without the pressure of external logics which are mainly political and economic (Schultz, 2007, p.192; Benson in Benson \& Neveu, 2010, p.99).

Sen and Hill (2007, p.56) argued that newspapers which survived the turbulence in the time of the Old Order-New Order transition immediately transformed its political support into economic benefit. They lobbied the New Order government to include the press into the Domestic Investment Act announced in July 1968, which provides tax concessions for imported goods (including paper) as well as government loans. The press had shifted from the ideological tool of political groups into industries that produce goods for the market.

The press was not only used as a field of influence by actors in the political field but are also able to become an actor who took advantage from political actors, including the government. Transforming political support into economic gain is the evidence. As the domestic economy grew, some newspapers received important loans from state banks. Kompas, for example, in 1972 borrowed $75 \%$ of all its capital needs to buy a new printing machine that allowed them to cut production time. By the mid-1970s, the amount of newspaper circulation had returned to the position as it had been before the events of 1965 and continued to grow until the 1990s. Hence, the position of the journalistic field during New Order was unique. While the journalistic field was controlled mainly by the political field during the Old Order era, it was under the control of political and economic fields at once during the New Order era.

New Order had never been happy seeing the journalistic field flourishing and advancing because it only means one thing: more critical media and bigger power to mobilize the public against the government. Therefore, the New Order regime imposes political and economic restrictions aimed at media companies.

Surabaya Post reporters and chief editors were interrogated by the Regional V/Brawijaya Military Command related to a news item which considered as cornering the military practices which at that time interferes in many legal cases. This is an evidence of how the political field continually sought to control journalism arena. It is true that none of the Surabaya-based newspaper was suspended like the ones in Jakarta, however the repression and intimidation against journalists considered as "endangering stability" never ceased in Surabaya. The forms of intimidation were diverse, ranging from as subtle as phone calls asking newspapers not to publish a certain event or issue in the presence of intelligence apparatuses in the field where the journalists operate. Repression in the form of 
journalist's detention was recorded once. The founder of Memorandum daily, Agil H. Ali was detained in 1978 when his newspaper, Mingguan Mahasiswa, published student movements that criticized the New Order. Agil was jailed after giving a speech in front of students from many universities in East Java commemorating World Human Rights Day at Airlangga University (Pitono, 2005, p. 83-89).

The more economical scrutiny includes a restriction on the number of pages and advertisement (ad) volumes. Through the Press Council, the government limits the ad volume to a maximum of $35 \%$ of the total available columns. By July 1986 , the number of newspaper pages was limited to 12 pages, which can be increased to 16 pages twice a week with special permission. This restriction was loosened in January 1990 to allow media companies publish 16 pages newspapers four times a week. Finally, since March 1991, daily newspapers can be published with 16 pages every day. On January 1992, the Press Council requested that the page number limit is increased to 20 pages (Hill, 2007, p.48, 58). The control over the number of pages and volume of ads disappeared as the New Order government collapsed in 1998. Print media can publish newspapers without any limit on the number of pages and ad volume ever since.

Dual control towards the press practiced by New Order, according to Champagne (in Benson \& Neveu, 2010, p. 49-50) prove that the journalistic field was deemed as too important to be allowed to operate using its own logic. Newspapers and journalists who were "fighting for their autonomy within the journalism arena" faced two constraints; namely strict political rules of the regime and to include business variables within the management of the newspaper.

Many parties began to question the shift in the press paradigm from the press of struggle into the commercial press. At some point, the two paradigms were seen as diametrically opposing in the sense that commercial press which seeks for profit was perceived as a threat to the "sacred" editorial independence and the essence of press freedom. Here the issue of commercialization as outlined by Benson (2006, p.193) and McChesney (2004, p.138) found its ground in Indonesia.

What came later was the debate over professional ethics. Newspapers (and all other types of media) have to deal with what Champagne (in Benson \& Neveu, 2010, p.48) called as "double dependency". The press was caught in the middle of an absolute competition between "freedom of the press" and "laws of the market". The press was trapped under the pressure of political field and economic field which aimed to control the editorial aspect of media (Dahlan cited in Siahaan \& Purnomo, 1993, p.530).

Benson (2006, p.193) asserted that commercialization will have implications on journalism ethics, among which manifested in the collapse of firewall that traditionally differentiates editorial domain and business domain, especially advertising. Founder of Kompas, Jakob Oetama, in a number of his writings has pointed out about this tendency for a long time. Oetama (2001b, p.116) argued that at least until 1970, newspapers strictly prohibited journalists from direct contact with companies and other potential advertisers. It was to minimize the influence of advertisers in the editorial decisions.

Advertisement holds a very important position within publishing companies since it brings income. The heightening vital position of the advertisement within a publishing structure is an evidence of how the publishing company responded to capitalism, hence another evidence that the logic of economic field as highly influencing the journalism arena. 
In 1988 , when there were no television commercials, newspapers absorbed $52 \%$ of total national advertising expenditure, while magazines took 19\%. In 2015, the table was turned. TV absorbed $71.7 \%$ of total advertising expenditure while combined print media got only $28.2 \%$ (Ulum, 2015).

Commercialization altered the competition within the journalism arena. At the beginning of the New Order era, or at least until the end of the 1970s, Surabaya Post was the single main player in Surabaya and East Java without any significant competitors. The acquisition of Jawa Pos daily by PT Grafiti Pers, a big media company, and the establishment of a new daily, Surya, by Poskota, another big media company, altered the competition. It marked the expansion of Jakarta-based big media companies to tap into the provincial market. Local market leaders such as Surabaya Post was not alone anymore in exploiting the market. Jakarta-based media companies acquired local media companies or develop new ones because they have big capital in doing that.

As a result, Surabaya Post's reign as the only commercial paper dropped. At the end of the 1980s, Surabaya and East Java, in general, were occupied by four regional newspapers, namely Surabaya Post, Memorandum, Jawa Pos, and Surya. In 1989, Surya was bought by Kompas-Gramedia Group which boost its circulation into 160,000-200,000 copies, capable enough to compete with Jawa Pos and Surabaya Post in a regional market. The dominance of the big four made other smaller local players such as Bhirawa and Karya Darma seek refuge within a niche market with limited readers. Both Bhirawa and Karya Darma which born in the same year, 1971, clung on the not really prospective market: government bodies.

Meanwhile, Karya Darma at first was published as weekly and became daily in 1993 after it was taken by Jawa Pos in 1992. The life of Karya Darma was in large part saved by the government program. Department of Information launched a program dubbed as koran masuk desa (bringing newspapers to villages) in February 1980 which aims to develop a reading habit among villagers and dwellers of small townships. Print media participating in the program received a special subsidy for their willingness to provide special reports about village development. This program helped Karya Darma to boost their circulation into about 26 thousand copies across East Java. The fact that newspapers sharpened their segmentation in order to secure readership has marked the deeper connection between journalistic field and economic field which was overlooked at the Colonial and Old Order eras.

\section{Reform Era: The Strengthening of Commercialization of Journalistic Field}

This era was marked by the fall of the New Order regime in 1998 which had a major impact on the dynamics of the journalism arena, especially in relation to the economic arena. The loss of state control and the rise of press freedom opened the door of liberalization which then paved the way for stronger commercialization and media conglomeration that actually started since the New Order era. This commercialization trend is a logical implication of the unrestrained capital transformation. On the next turn, this wave of commercialization is increasingly putting advertising interest as a very important part and its influence permeated into the editorial boardroom which affected editorial independence.

After the New Order collapsed in May 1998, fundamental changes did take place in the political field and the economic field which had a very significant impact on the journalism arena. The most notable one was the collapse of various state controls over the 
press license restriction which suggests the collapse of the political field against the journalism arena. President Habibie had an important part in ending the various state controls that shackled the press freedom during the New Order regime. Replacing Soeharto as president abruptly in May 1998, Habibie had to face a surge of pressure to reform the political system inherited from his predecessor. Only a few weeks after his presidency, Habibie launched a series of policies that changed the political system, which had a very rapid and significant impact on press freedom and daily journalism practice (RomanoSeinor, 2005, p.111). Despite continuing to be the target of media criticism of his government, Habibie keeps issuing a number of rules protecting press freedom and journalist rights (Romano, 2003, p.49-51). The most significant one was the initiation of a law-making process which finally eliminated the SIUPP (press license), a scourge for press community for long.

The disappearance of SIUPP means the loss of very strict rules licensing print and electronic media publishing which made the number of print media soaring. The Department of Information provided about 1,800 to 2,000 new SIUPPs (Romano, 2003, p.35) after the ease of regulation. Armando (2014, p.394) stated that while Indonesia has only 289 print media in 1997, this number soared into 1,381 in 1999 and increased to 1,881 in 2001.

On the other hand, the liberalization which was preceded by the transformation of capital (in the New Order era) also had implications for the emergence of what Tempo Magazine former chief editor, Bambang Harymurti called as media cartelization (Harymurti, 2010, p.17). The map of media ownership in Indonesia shows that in 2013, there 10 groups dominated a vast majority of media ownership: Tempo Group, Beritasatu Group, Media Group, Kompas Group, Jawa Pos Group, Media Bali Post, Bakrie and Brothers Group, Surya Citra Media, MNC Group, and Trans Corp (Sudibyo-Patria, 2013, p. 267-270).

This phenomenon occurs both in global and national contexts. At the global level, this cartelization or media concentration has been predicted by academics such as McChesney (2000), Lieberman-Esgate (2002), Doyle (2002), and Baker (2007). This tendency suits Benson's (2006, p.193) argument that describes it as a form of capitalist transformation in the mass media world which brought more intense commercialization or profit-making interests. The number of media was skyrocketing which is ironic, considering the increase of concentrated media ownership.

In the 2000s, a lot of new media were established, while some old newspapers were restructured by new owners through large investment injections. The mass media industry was increasingly acknowledged as a profitable business and investment which saw a lot businessmen and politicians racing into the arena. The ten largest media groups were owned by politicians and businesspeople. The three owners of media conglomerates, Surya Paloh (Media Group) Aburizal Bakrie (Bakrie \& Brothers Group), and Hary Tanoesoedibjo (MNC Group) even played a double role as businessmen and politicians. Surya Paloh became a member and Chairman of the Democratic National Party, Aburizal Bakrie active in the Golkar Party (he was once its chairman) and held ministerial position during Susilo Bambang Yudhoyono's presidency, and Hary Tanoesoedibjo became the chairman of Perindo Party. Discussions about mass media were no longer dominated by sacred values discourses like serving the public interest or acting as the fourth estate of democracy, but instead was associated with capital and profit. The strong pressure of profit-seeking logic of the 
economic field even transformed the journalists' habitus from obeying the journalistic firewall into almost completely ignoring it.

It is like living nearby to a railway. At first, we are disturbed by the noise of the train. ... However, after a while, we get used to it and see it as normal (MA, journalist of Bhirawa, personal interview on 23 April 2016).

Right from the beginning I join Duta Masyarakat, I was assigned to seek for advertisement in East Java Governor Office. I am ok with that since I also benefitted from it. The commission from advertisement was quite big and I was looking for it when I hunt for news. It is fine, I get used to it and all reporters posted in the Governor Office do the same (FAS, former reporter of Duta Masyarakat, personal interview on 2 March 2016).

This habitus transformed the journalists from independent intellectuals serving the community into merely employees of media companies who are easier to be dictated. In terms of gaining power, media owners can use their own media as an umbrella to protect their business and political interests. The habitus of serving the company internalized by many journalists made it easier for the media owner to use the company (and the journalists) to serve the owner's interests.

Tapsell (2012) shows how media conglomerate owners like Surya Paloh (Media Group), Aburizal Bakrie (Bakrie \& Brothers), Dahlan Iskan (Java Pos Group), or James Ryadi (Grup Beritasatu) use their respective media to protect and develop their economic and political interests. Surya Paloh, for example, used his media to raise the party he founded, the Democratic National Party and was previously used for his bid for Golkar Party's chairmanship against Aburizal Bakrie (who also used his Viva Group media network to win the chairmanship). Aburizal Bakrie also exploited the media related to the disaster of the Lapindo mudflow in Sidoarjo, while Harry Tanoesoedibjo used his TV stations to promote his Perindo Party. A number of media outlets also mobilized support for their owners and business groups when attacked by others. When Dahlan Iskan, in his capacity as minister of state-owned enterprises, was in conflict with the Indonesian House of Representatives, Jawa Pos put this conflict as the headline on page one for several days stating their unwavering support towards him.

In Surabaya, the fall of the New Order regime in 1998 shifted the newspaper competition. In a Bourdieuean term, the strong pressure from the economic field pushes the journalistic field closer to heteronomous pole. The competition between newspapers is no longer merely about content, but is also related to capital which was reflected in the scope of distribution and technology such as printing machine. Local newspapers must deal with Jakarta-based national newspapers printed in Surabaya. One of the biggest player in East Java, Surabaya Post officially announced its closure on 1 May 2002. Surabaya Post ceased to publish on the grounds of shortage of paper and failure to compete with Surya and especially Jawa Pos, another evidence that the changing competition environment has killed small and non-conglomerate related newspapers. Karya Darma was another fatality of the Reform era. The collapse of the New Order regime means no one supported Karya Darma circulation anymore. 


\section{CONCLUSION}

The Surabaya journalistic field was more connected to the political field during the Colonial and Old Order eras. The struggle to free Indonesia from colonial ruler attracted journalists to function both as journalist and patriot. They distributed independence-inspiring news and resisted colonial ruler's policies which were deemed as unfair. Indonesian journalists in Colonial era defied actors with massively bigger power (colonial ruler) without adequate specific cultural capital. It contradicts Bourdieu thesis that said journalistic field needs strong cultural capital to stay on the autonomous pole.

During the Old Order era, the connection to political field was still very strong. Most of the journalists and the press were connected or even financed by political parties and mass organizations which made them prone to partisanship. The connection between journalistic field and the economic field began during the New Order era and got more intense and massive in the Reform era, among which was marked by the emergence of cartelization of media ownership.

However, in the context of Surabaya, commercialization (the overlap between journalistic and economic fields) had begun to appear, albeit vaguely, since the Old Order era through the birth of Surabaya Post, a daily which was established more in response to the market rather than to a particular political ideal and interest. It suffices to say that Surabaya pioneered the commercialization of the journalistic field in Indonesia. New Order and Reform era posit as double pressure to journalism era. Journalists and media companies were constantly under pressure to stay autonomous, both from partisan political interest and the lure of financial gain by compromising firewall. $\left({ }^{*}\right)$

\section{BIODATA}

Nanang Krisdinanto is a senior lecturer at Widya Mandala Catholic University, Surabaya. The author is currently doing his PhD at Airlangga University, Indonesia.

Achmad Supardi is a senior lecturer at the Communication Department, Faculty of Humanities, President University, Cikarang, Indonesia. He was previously a managing editor at Surabaya Post. 


\section{REFERENCES}

Ariyansyah, Ganie, K. G., \& Ruslinur, D. (1996). Titian pers Lampung: Etos perjuangan di tanah

Lampung. Jakarta: Permata.

Armando, A. (2014). The greedy giants: Centralized television in post-authoritarian Indonesia. International Communicaton Gazzette, 79.

Atmakusumah. (1980). Kasus Indonesia raya. In A. Surjomihardjo (Ed.), Beberapa Segi dalam Perkembangan sejarah pers di Indonesia. Jakarta: Departemen Penerangan RI: LEKNAS-LIPI.

Baker, E. C. (2007). Media concentration and democracy: Why ownership matters. Cambridge: Cambridge University Press.

Benson, R. (2006). News media as a 'journalistic field': What bourdieu adds to news institutionalism, and vice versa. Political Communicaton, 23.

Benson, R., \& Neveu, E. (2010). Bourdieu and the journalistic field. Cambridge: Polity Press.

Bourdieu, P. (1993). The field on cultural production: Essays on art and literature. Cambridge: Polity Press.

Bourdieu, P. (1998). On television. New York: New Free Press.

Compton, J. R. \& Benedetti, P. (2010). Labour, new media and the institutional restructuring of journalism. Journalism Studies, 11(4), 487-499. doi: 0.1080/14616701003638350

Doyle, G. (2002). Media ownership: The economics and politics of convergence and concentration in the UK and European media. London: Sage Publications.

English, P. (2016). Mapping the sports journalism field: Bourdieu and broadsheet newsrooms. Journalism, 17(8), 1001-1017. doi: 10.1177/1464884915576728

Hanazaki, Y. (1998). Pers terjebak. Jakarta: Institut Studi Arus Informasi.

Harymurti, B. (2010). Under the rule of press law. Walkley Magazine, April 2010.

Hill, D. T. (2007). The press in new order Indonesia. Jakarta: Equinox.

Hill, D. T. (2011). Jurnalisme dan politik di Indonesia: Biografi kritis Mochtar Lubis (19222004) sebagai pemimpin redaksi dan pengarang. Jakarta: Yayasan Pustaka Obor Indonesia.

Liebermen, A., \& Esgate, P. (2002). The entertainment marketing revolution: Bringing the Moguls, the media, and the magic to the world. New Jersey: Prentice Hall.

Lim, M. (2012). Lim: Map of media concentration in Indonesia. Academia.edu. Retrieved from

https://www.academia.edu/10206271/Lim_Map_of_Media_Concentration_in_Indo nesia

Marliere, P. (2001). The impact of market journalism: Pierre Bourdieu on the media. The Sociological Review, 49(S1), 199-211. doi: 10.1111/j.1467-954X.2001.tb03542.x

McChesney, R. W. (2000). Poor media, rich democracy: Communication politics in dubious times. New York: The New Press.

McChesney, R. W. (2004). The problem of the media: US communication politics in the 21st century. New York: Monthly Review Press.

McManus, J. H. (2009). The commercialization of news. In K. W. Jorgensen \& T. Hanitzsch (Eds.), The handbook of journalism studies. New York: Routledge.

Oetama, J. (2001a). Pers Indonesia: Berkomunikasi dalam masyarakat tidak tulus. Jakarta: Kompas.

Oetama, J. (2001b). Dunia usaha dan etika bisnis. Jakarta: Kompas. 
Pitono, D. (2005). Aktor besar di panggung kecil: Perjalanan, pikiran dan perasaan Agil H. Ali. Surabaya: Lutfansah Mediatama.

Ritzer, G., \& Goodman, D. J. (2004). Teori sosiologi modern. Jakarta: Kencana.

Romano, A. (2003). Politics and the press in Indonesia: Understanding an evolving political culture. London: Routledge.

Romano, A., \& Seinor, B. (2005). Between dictatorship and democracy: State-affiliated news media in Indonesia. In R. Angela \& M. Bromley (Eds.), Journalism and democracy in Asia. London: Routledge.

Sen, K., \& Hill, D. T. (2007). Media, culture, and politics in Indonesia. Jakarta: Equinox.

Setiono, N. G. (2008). Tionghoa dalam pusaran politik: Mengungkap fakta sejarah tersembunyi orang Tionghoa di Indonesia. Jakarta: Transmedia.

Siahaan, H. M., \& Purnomo, T. (1993). Tajuk-Tajuk dalam terik matahari: Empat puluh tahun Surabaya Post. Surabaya: Yayasan Keluarga Bhakti.

Swantoro, P., \& Atmakusumah. (2002). Pembredelan pers dalam sejarah Indonesia. In A. Surjomihardjo (Ed.), beberapa segi perkembangan sejarah pers di Indonesia. Jakarta: Departemen Penerangan RI dan LEKNAS-LIPI.

Tim LP3Y. (2006). Jurnalis Indonesia di Lima Kota: Memahami preferensi jurnalis dalam meliput AIDS, gender dan kesehatan reproduktif. Jogjakarta: LP3Y.

Tim SPS. (1994). Pers jatim dari masa ke masa. Surabaya: Serikat Penerbit Suratkabar Jawa Timur.

Schultz, I. (2007). The journalistic gut feeling: Journalistic doxa, news habitus, and orthodox news values. Journalism Practice, 1.

Sudibyo, A., \& Patria, N. (2013). The television industry in post-authoritarian Indonesia. Journal of Contemporary Asia, 43.

Ulum, M. (2015). Belanja iklan TV naik 95, Koran minus 8\%. Bisnis.com. Retrieved from http://surabaya.bisnis.com/read/20150820/8/82800/belanja-iklan-tv-naik-9-koranminus-8 
APPENDIX 1: List of informants.

\begin{tabular}{|c|c|c|c|c|}
\hline No & Name & Newspaper & Position & Date of Interview \\
\hline 1 & M. Bakir & Kompas & Managing Editor & 4 February 2016 \\
\hline 2 & Agnes Swetta Pandia & Kompas & $\begin{array}{l}\text { Bureau Head, } \\
\text { Kompas East Java } \\
\text { Bureau }\end{array}$ & 17 February 2016 \\
\hline 3 & Dahlia Irawati & Kompas & $\begin{array}{l}\text { Reporter, based } \\
\text { in Malang }\end{array}$ & 24 February 2016 \\
\hline 4 & Subur Tjahjono & Kompas & $\begin{array}{l}\text { Former Editor, } \\
\text { now Newsroom } \\
\text { Secretary }\end{array}$ & 5 June 2016 \\
\hline 5 & Farhan Effendy & Surya & $\begin{array}{l}\text { Executive } \\
\text { Managing Editor }\end{array}$ & 1 April 2016 \\
\hline 6 & Tri Hatmaningsih & Surya & Senior Editor & 5 February 2016 \\
\hline 7 & Nurwahid & Jawa Pos & Chief of Editor & 21 March 2016 \\
\hline 8 & Glandy Burnama & Jawa Pos & Reporter & 2 February 2016 \\
\hline 9 & Maksum & Jawa Pos & Former Editor & 3 February 2016 \\
\hline 10 & Choliq Baya & Radar Jember & $\begin{array}{l}\text { Director, former } \\
\text { Chief of Editor }\end{array}$ & 10 February 2016 \\
\hline 11 & Lainin Nadziroh & Radar Surabaya & $\begin{array}{l}\text { Advertorial } \\
\text { Manager, former } \\
\text { Senior Reporter }\end{array}$ & 13 April 2017 \\
\hline 12 & M. Ali & Bhirawa & Reporter & 23 April 2016 \\
\hline 13 & Azis Tri Priyanto & Berita Metro & Editor & 21 February 2016 \\
\hline 14 & Noor Arief Prasetyo & Memorandum & Editor & 6 April 2016 \\
\hline 15 & Rahmad Hidayat & Memorandum & Reporter & 6 April 2016 \\
\hline 16 & Syahbandiah Esha & Memorandum & Former Editor & 1 February 2016 \\
\hline 17 & Erfandi Putra & $\begin{array}{l}\text { Surabaya Post } \\
\text { (late), Duta } \\
\text { Masyarakat }\end{array}$ & Editor & 6 February 2016 \\
\hline 18 & Djoko Pitono Hadiputro & $\begin{array}{l}\text { Surabaya Post } \\
\text { (late) }\end{array}$ & Editor & 30 March 2016 \\
\hline 19 & Riadi Ngasiran & Duta Masyarakat & Editor & 20 June 2016 \\
\hline 20 & Oryza Setiawan & $\begin{array}{l}\text { Jatim Mandiri, } \\
\text { Surabaya Pagi }\end{array}$ & Former reporter & 10 February 2016 \\
\hline 21 & Prasto Wardoyo & $\begin{array}{l}\text { Independent } \\
\text { Journalist } \\
\text { Association (AJI) } \\
\text { Surabaya }\end{array}$ & Chairman & 26 March 2016 \\
\hline 22 & Machmud Suhermono & $\begin{array}{l}\text { Indonesian } \\
\text { Journalists } \\
\text { Associations } \\
\text { (PWI) Surabaya }\end{array}$ & Secretary & 24 March 2016 \\
\hline
\end{tabular}

